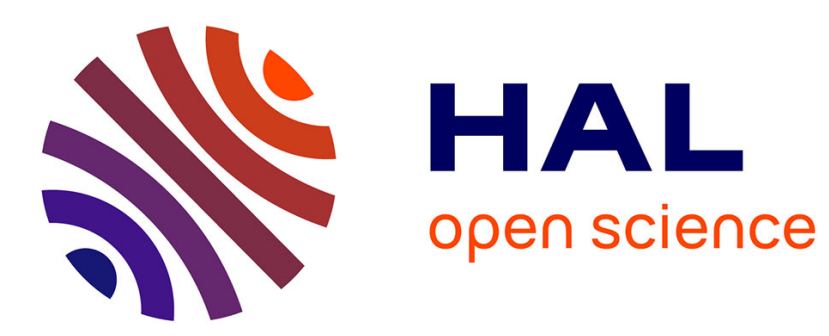

\title{
LOW POWER CW LASER LIGHT IN NEW NONLINEAR OPTICAL MATERIALS
}

\author{
M. Dumitru, I. Popescu, M. Honciuc
}

\section{To cite this version:}

M. Dumitru, I. Popescu, M. Honciuc. LOW POWER CW LASER LIGHT IN NEW NONLINEAR OPTICAL MATERIALS. Journal de Physique IV Proceedings, 1991, 01 (C7), pp.C7-757-C7-760. 10.1051/jp4:19917203 . jpa-00250884

\section{HAL Id: jpa-00250884 https://hal.science/jpa-00250884}

Submitted on 1 Jan 1991

HAL is a multi-disciplinary open access archive for the deposit and dissemination of scientific research documents, whether they are published or not. The documents may come from teaching and research institutions in France or abroad, or from public or private research centers.
L'archive ouverte pluridisciplinaire HAL, est destinée au dépôt et à la diffusion de documents scientifiques de niveau recherche, publiés ou non, émanant des établissements d'enseignement et de recherche français ou étrangers, des laboratoires publics ou privés. 
JOURNAL DE PHYSIQUE IV

Colloque C7, supplément au Journal de Physique III, Vol. 1, décembre 1991

C 7-757

\title{
LOW POWER CW LASER LIGHT IN NEW NONLINEAR OPTICAL MATERIALS
}

\author{
M. DUMTTRU, I.M. POPESCU and M. HONCIUC \\ Dept. of Physics, Polytechnical Institute of Bucharest, Spaiul Independentei 313, Bucharest 77206, \\ Romania
}

\begin{abstract}
The Ilquid crystal smectic C-type properties of some fatty acids and their mixtures with cholesterol were proved. 3y using low power losers (He-re) nonlinear optical effects, depending on the cholesterol percentage, were obtained.
\end{abstract}

\section{1.-Introduction}

A creat number of experimental data indicate that the liquid crystal stete is croracteristic of some complex molecular structures belonging to the Iiving matter.

It was proved that many fatty acids exhibit a smectogenic behaviour/1/\% An example is the arrachidic acid $\mathrm{CH}_{3}\left(\mathrm{CH}_{2}\right)_{18} \mathrm{COOH}$ - a soturated fatty acid, constituent of phospholipides. ${ }^{2}{ }^{2}$ rogm temperature, it is a white crystalline powder, but within $70-75,3^{\circ} \mathrm{C}$ it exhibits a smec-

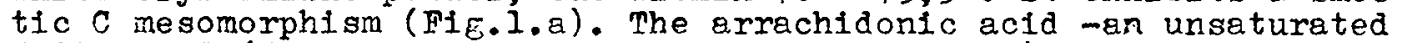
latty acid (four double chains at $5,8,11$ and $14 \mathrm{C}$ ) -is a constituent of the bjological membrane and a forerunner of the prostaglendines. It exhlbits a mesogenic behaviour between $4-20^{\circ} \mathrm{C}$. At higher temperature, it decoys;at room temperature it is a yellowish oleous liquid. By means of electric measurements, some dielectrical properties of these substances were emphasized; they present a certain conductibility, too. The same investigations, performed on the fatty acid-cholesterol mixtures, in different pexcentages by weight, show that:

- the cholesterol enhances the mesomorphic range with $10-15^{\circ} \mathrm{C} / 2 /$;

- the cholesterol influence on the saturated acid was different in comparison with the unsaturated one $/ 2 /$.

Taking into account these observations, other saturated and unsaturated fatty acids were subject of the same investigations:

- the lauric acid $\mathrm{CH}_{3}\left(\mathrm{CH}_{2}\right)_{10} \mathrm{COOH}$ - a saturated fatty acfd, displays



- the elaidic acid (the trans-isomer of the oleic acid) - an unsaturated fatty acid ( a gouble chain at $9-10 \mathrm{C}$ ), is a smectic liquid crystal between 41 - $51^{\circ} \mathrm{C}$ (Fig.1.b).

The electric measurements performed for these acids led to similar conclusions as those previously exposed.

By studying a great number of works pubilished until now (see, for example, $/ 3 /)$, one can observe that the materials which are neither pure metals, nor dielectrics - like semiconductors and liquid crystals - exhibit a great optical nonlinearity.Our ideea is to use low optical power lasers, which should be able to excite such a great npticel nonlinearity. Indeed, external self-focusing of a He-re laser 




a)

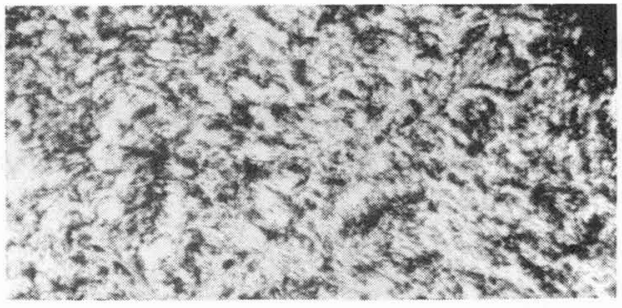

b)

Fig.1.-Microstructural aspects of some fatty acids with smectogenic behaviour: a) - a saturated fatty acid (the arrachidic acid); b) b) an unsaturated fatty acid (the elaidic acid):"Cell'thickness $d=13,5$ um

beam was obtained for TEII and TEW modes. Again, the cholesterol percentage influenced difierently the optical behaviour of the saturated and ungaturated acids, respectively.

\section{2.-Electric measurements}

Current-voltage plots $I=I(U)$ at constant temperature for pure acids and for mixtures were obtained. When the cholesterol is added, the area of the hysteresis increases for the saturated acids (Fig.2.a,c), but decreases for the unsaturated ones (Fig.2.b,d). The same results were obtalned for the other two acids.

Other characteristic measurements: $I=I(t), t$ being the time; $I=I(\omega)$, where $\omega$ is the frecquency of the 8 .c. applied field; $I=I\left(\theta^{\circ} \mathrm{C}\right)$, performed for pure acids and for mixtures, confirm the previous conclustons $/ 2,4 /$.

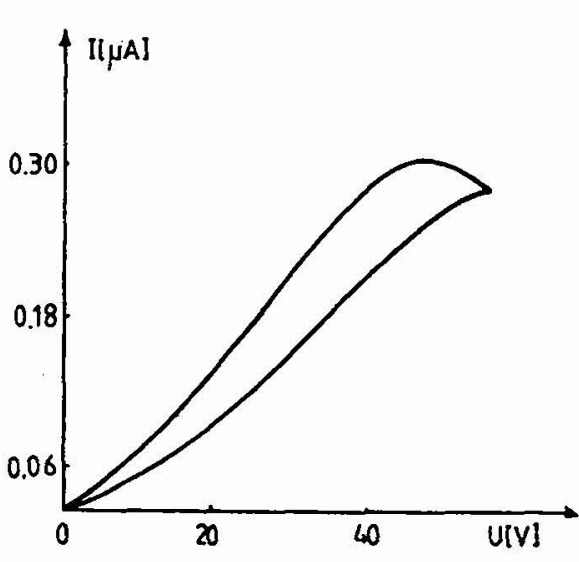

a)

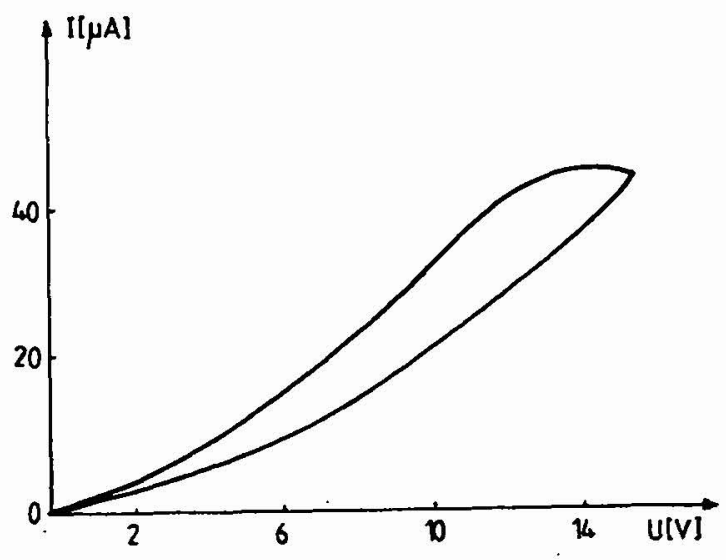

b)

Fig.2.-Current-voltage plots $I=I(U)$. a) - arrachidic acti; b) - errechidonic acid 


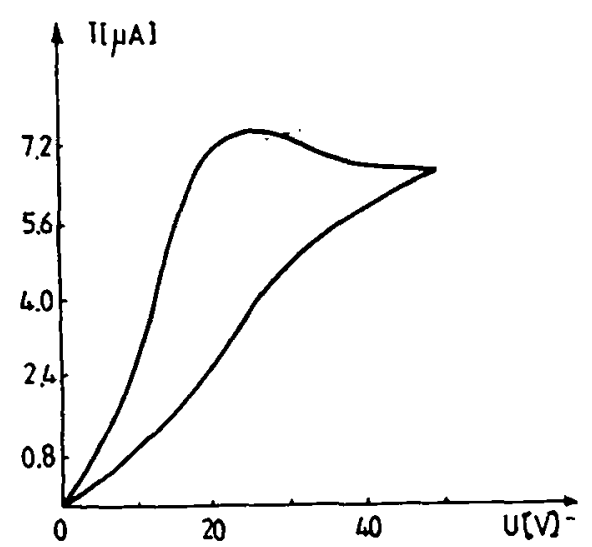

c)

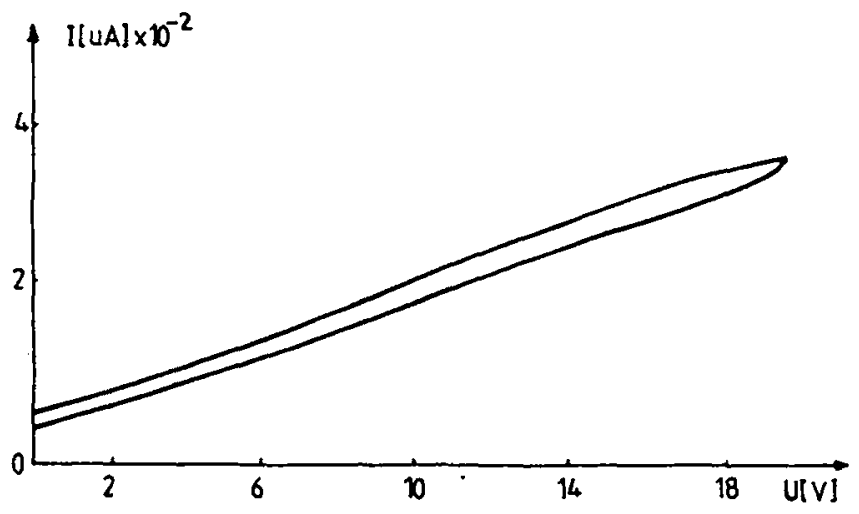

d)

Fig.2. Current-voltage plots $I=I(U) . c)-2-1$ arrachidic acid-cholesterol mixture; d)- 1-2 arrachidonfs acid-cholesterol mixture

3.-Nonlinear optical behaviour

The nonlinear optical effects, obtained with a He-Ne laser (HHA 188RDG $, \lambda=6328 \mathrm{~A}, \mathrm{P}_{\mathrm{max}}=20 \mathrm{~mW}$ ) are in eccordance with the former ones.

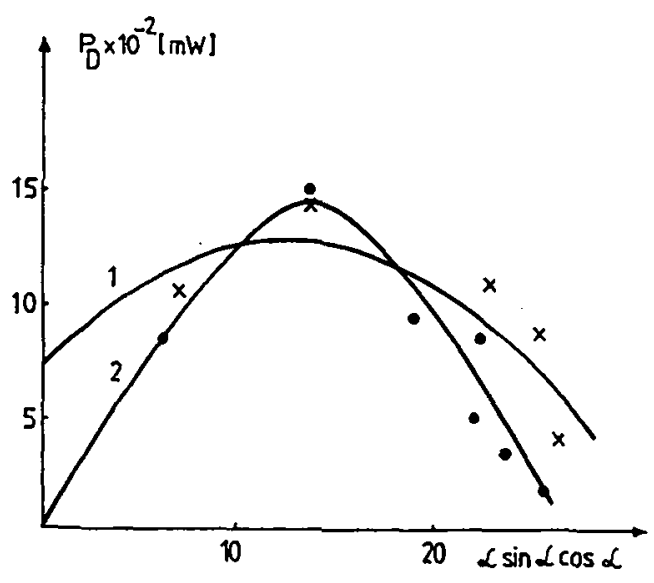

Fig.3.-Diffracted power $P_{D}$ of the focused laser beam, when the sample was outside the focus (1) and just in the focus (2); $\alpha$-incidence angle

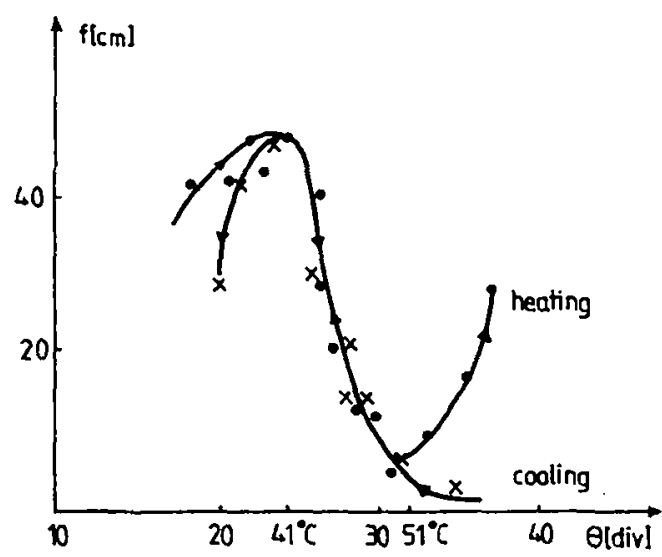

Fig.4.-Ionlinear focal length of an elaidic acid sample versus temperature ( ldi $\left.=1,55^{\circ} \mathrm{C}\right)$

A great opticel nonlinearity was observed for the samples of arrachidonic acid. Because the refractive index in the center of the beam differs from that one at the edge of the beam, the sample behaves like a convergent lens and a spatial self-phase modulation takes place. A ring pattern can be observed on a screen in far field /4/. In arrachidonic acid-cholesterol mixtures this effect is null. In arrechidic acid the result is 8.1 so necetive, but in its mixtures a distortion of the wave-front was observed. 


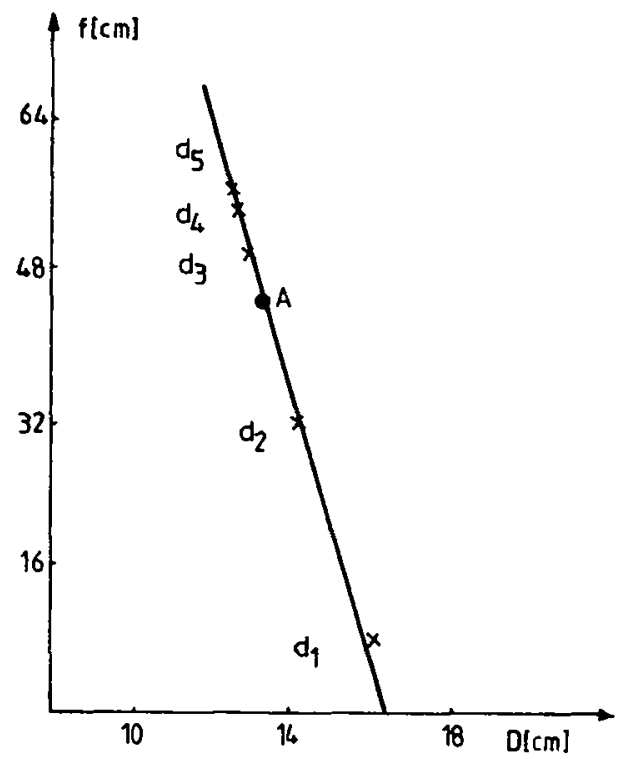

Tig.5.-"onlinear focal length $\rho$ versus the beom divergen-

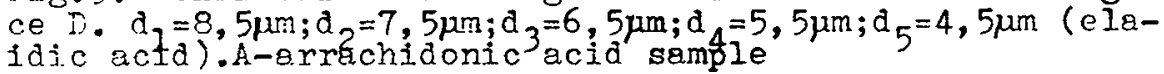

In elaidic acjd the effect is positive, but in lauric acid no ring pattern was obtained;th1s one appears in some of $t$ ts mixtures with cholesterol / $4 /$.

For the unsaturated acids other measurements were made, too: the diffracted power $P_{F}$ as a function of ar incidence parameter of the light focused bean on the liquid crysta! cell with arrachidonic acid (Fig.3); the "nonlinear focel length" of an elaidic acid sample as a function of ${ }^{\circ}$, when being heated and cooled (F1g.4); the "nonInear focal length " of semples containing both unseturated acids versus the beam divergence $D$, measured on the screen (Fig.5).

\section{4.-Conclusions}

New smectic Ifquid crystels for nonlinear optics were obtained and studied:saturated and unsaturated fatty acids and their mixtures with cholesterol. Their electric and nonlinear optical behaviour is differently influenced by the cholesterol. We think the explanation is related to the generation of a space charge Induced by the presence of the cholesterol.

\section{References}

/1/ SINGER, P.O.,"Structure and Functions of Biological Membranes", Academic Press, Hew-York, 1971

/2/ HONCIUC, M., C.MOTOC, M.DUMITRU, R.MITROI, I.STERIAN, R.HONCIUC, "European Conf. on Liquid Crystals", Valle d'Aosta, Italy, March ig91 13/ BOWDEN,CH.M.,H.ROBI,M.CIFTAN, "Optical Bistability", Plenum Press, 1980

/4/ DUMTTRU,M., Doctor's thesis, I.F.A.Bucharest,1990 (unpublished), 